\title{
DIGITÁLIS KATALÓGUS TERVEZÉSE
}

\author{
Varga Ádám \\ MSc hallgató, Miskolci Egyetem, Gépészmérnöki és Informatikai Kar \\ Automatizálási és Infokommunikációs Intézet \\ 3515 Miskolc, Miskolc-Egyetemváros, email: varga.adam@uni-miskolc.hu
}

\begin{abstract}
Absztrakt
A cikkemben bemutatott eszköz egy olyan innovativ katalógus-vezetésre alkalmas eszköz, amelyet széles körben lehet alkalmazni. Az eszköz segitségével digitális formában lehet katalógust vezetni, ami rengeteg csalási lehetöséget zár ki. Olcsó NFC matricák/kártyák segitségével müködik ez a hordozható rendszer, amelynek használata igen egyszerü. Az NFC kártyák segitségével azonosithatják magukat a diákok. Az eszköz kiolvassa az NFC chip egyedi azonositóját, amit egy elözöleg megtanitott névvel rendel össze. Az így megkapott nevet pedig egy SD kártyára menti el egy idöbélyeggel együtt.
\end{abstract}

Kulcsszavak: Arduino IDE, NFC, ESP8266, SD, RTC

\begin{abstract}
The tool presented in this article is an innovative catalog management tool that can be widely used. The tool allows you to maintain a digital catalog, which exploits a large number of fraudulent opportunities. Cheap NFC stickers / cards make this portable system easy to use. NFC cards allow students to identify themselves. The device reads the unique ID of the NFC chip, which is associated with a previously learned name. The name you get is saved on an SD card along with a time stamp.
\end{abstract}

Keywords: Arduino IDE, NFC, ESP8266, SD, RTC

\section{Bevezetés}

Az egyetemen az órák látogatását a tanárok sokszor katalógus vezetésével ellenőrzik. Ez legtöbb esetben egy A4-es lapon történik, ahol az ott lévő diákok feltüntetik a nevüket, Neptun kódjukat, illetve az aláírásukat. A technika fejlődésével és a különböző chat alkalmazások elterjedésével a diákok sokszor megkérik egymást, hogy „hamisítsák” a barátaikat, társaikat fel erre a lapra. Ez ellen a tanárok sokszor úgy védekeznek, hogy az óra végén felolvassák a lapon lévő neveket, és az ott levő diákoknak jeleznie kell, hogy ott vannak-e. Ezt abban az esetben egyszerü megtenni, ha nem nagy a hallgatói létszám, viszont, ha nagy a hallgatói tábor, akkor ez a folyamat hosszadalmas és könnyen kijátszható. Erre a problémára nyújt megoldást az általam készített eszköz.

\section{Eszköz ismertetése}

Az én eszközöm egy olyan katalógus vezető szerkezet, amellyel az elöbb felsorolt akadályokat lehet kiküszöbölni. Mind ezek mellett a katalógus íratás folyamata is gyorsul, hiszen nem kell egy papíron a jelenlévők nevét, illetve Neptun kódját feltüntetni. Az eszköz hasonlóképpen müködik, mint ahogy a nagy raktárokban a raktárkészlet nyilván tartása müködik [1]. NFC címkével vagy a diák igazolványban található RFID kártyával azonosíthatják a diákok magukat. A jelenlét ellenőrzését annak érdekében, hogy a diákok többsége megjelenjen az óra egészén, ezért tetszés szerint az óra időtartamán belül bármikor ellenőrizhető. Ekkor minden jelen lévő diáknak hozzá kell érintenie a 
matricáját/diákigazolványát egy kis dobozkához, ami egy excel fájlba elmenti az aktuális időt, a diák nevét és a Neptun kódját. Az adatmentést egy kis mikro SD kártyára menti a szerkezet, amelyet laptop segítségével bármikor ki tudunk olvasni. A mikrokontroller az NFC olvasó segítségével kiolvassa az NFC címkékből a címke UID-ját, ami minden címkének egyedi, ezután a mikrokontrolleren található adatbázissal összeveti a kiolvasott adatot. Ha adategyezést talál, akkor azt egy rövid hangjelzéssel jelzi, és a hozzá csatolt OLED kijelzőre kiírja az NFC címke tulajdonosának nevét. Ha egy olyan kártyát érintenek az olvasóhoz, amely nem szerepel az adatbázisban akkor egy magasabb hangot ad ki az eszköz magából és egy hibaüzenetet ír ki az OLED kijelzőre. A mikrokontroller azt az esetet is lekezeli, ha valaki egynél többször is fel szeretne iratkozni a katalógusra. Ebben az esetben is egy magasabb hangot fog kiadni a mikrokontroller, mint az előbbi esetben. Ezzel egy gyors, biztonságos digitális katalógus vezethető. További előnye, hogy a tanárnak nem kell tárolgatnia a katalógust, hanem maga az eszköz elmenti az adatokat, és az év végén a követelmények alapján kilistázza azoknak a diákoknak a nevét, akik nem jelentek meg az óráin elegendő alkalommal.

A mikrokontroller adottságai miatt megvalósítható, hogy az adott napi katalógus adatait e-mailben is elérhetővé tegye számunkra, ami egyfajta biztonsági mentésként is tekinthető. Ez továbbá egyfajta könnyebbséget ad az oktatók számára.

\section{Komponensek ismertetése}

\subsection{Mikrokontroller}

Az eszköz alapját egy ESP8266 SoC alkotja. Ennek a „mikrokontrollernek” számtalan elönye van. Kezdve a kis méretétől egészen a Wifi kapcsolat létesítésééig. Én a méretei miatt egy Wemos D1 mini mikrokontrollert használtam az eszköz megépítéséhez. Az Wemos D1 minin megtalálható az Espressif cég által tervezett ESP8266 SoC, ami fel van forrasztva egy másik nyáklapra, ami az ESP8266 lábait vezeti ki, ezen kívül egy USB/UART és egy 3,3 V-os feszültségstabilizátor is megtalálható ezen a nyáklapon. Így az ESP-t egy Micro USB kábel segítségével programozni is tudtam.

A Wemos alaplapon $11 \mathrm{db}$ digitális $\mathrm{I} / \mathrm{O}$ ki és bemenet és $1 \mathrm{db}$ analóg bemenet található meg. A Wemos D1 mini további előnye, hogy kis fogyasztása miatt nagyon könnyen akkumulátor telepre csatlakoztatható [3]. A kis fogyasztása a hordozhatóság miatt egy fö szempont volt. Továbbiakban amiatt választottam ezt a mikrokontrollert, mivel lehet Arduino IDE-n keresztül programozni. A Wemos D1 mini alaplapot az 1. ábra mutatja.

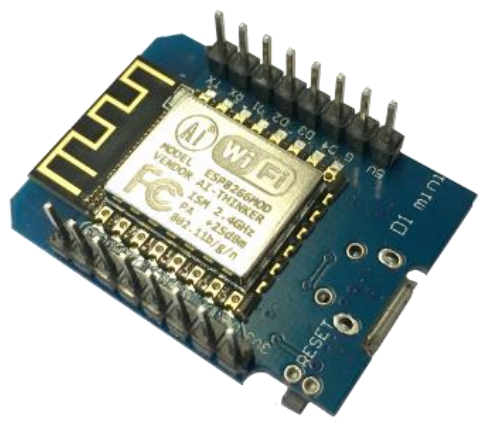

1. ábra. Wemos D1 mini 


\subsection{Adatok tárolása}

A Wemos D1 mini azért gondolom, hogy a legmegfelelőbb választás volt, mivel ehhez létezik nagyon sok olyan "shield”, aminek ugyanilyen alakja van és egyszerüen lehet csatlakoztatni a mikrokontrollerhez, ehhez csak a kivezetések tetejére rá kell tolni a kiegészítő elemet. Találtam egy olyan RTC-Micro SD shieldet amit a Wemos alaplap tetejére lehet csatlakoztatni. Későbbiekben ez a shiled fogja lementeni az NFC címkékből kiolvasott adatokat a Mirco SD kártyára. A nyáklapon megtalálható az SD kártya olvasásához/írásához szükséges alkatrészek, illetve azok a lábak, amelyeken keresztül kommunikálni lehet a kártyával. Az RTC a „Real-Time-Clock” angol kifejezés rövidítéséből állt össze. Az RTC továbbiakban abban lesz segítségül, hogy a pontos időt ki tudjuk belőle olvasni. A nyáklapon található IC-nek ha egyszer megmondjuk a pontos időt, akkor a kis gombelem táplálásáról ez az IC éveken keresztül pontos időt tud nekünk szolgáltatni anélkül, hogy még egyszer be kellene állítanunk. Ezt a shieldet a 2. ábrám szemlélteti.

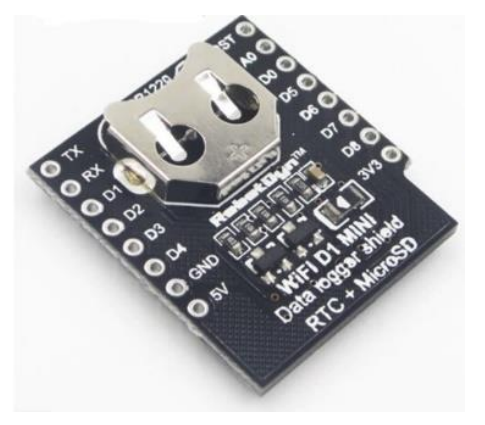

2. ábra. RTC, SD kártya modul

\subsection{NFC modul}

Az NFC (Near Field Communication) egy rövid hatótávú rádióhullámos kommunikációs szabványgyüjtemény. Az NFC egy olyan RFID rendszer, ami két irányú kommunikációt tesz lehetővé a végpontok között, ellentétben az olyan korai rendszerekkel, mint például az érintésmentes okos kártyák, melyek csak egyirányú kommunikációra (olvasás) alkalmasak. A mi esetünkben hasonlóan az érintésmentes kártyákhoz egy egyirányú kommunikációra van szükségünk, mégis az NFC szabványt használjuk. Ezt a szabványt azért részesítjük előnyben, hiszen ez a kommunikációs szabvány van az RFID szabvánnyal együtt legszélesebb körben elterjedve [2]. Többek között a diákoknak a diákigazolványába integrált chip is NFC kompatibilis. Ahhoz viszont, hogy a diákigazolványt használhassuk azonosítás gyanánt, ahhoz a kártya tulajdonosának bele kell egyeznie az adatrögzítési feltételekbe. Abban az esetben, ha ezt a procedúrát szeretnénk kikerülni, annyi a dolgunk, hogy egy olcsó NFC matricát osztunk ki a diákoknak, amelyet névre szólóvá teszünk.

Én a továbbiakban az óra részvételt NFC matricák segítségével ellenőrzöm. Ehhez a mikrokontrollerhez egy NFC olvasót társítottam. Ennek segítségével kiolvasható az NFC matricák egyedi UID kódjuk. A UID kódok kiolvasását egy NEC PN532 típusú NFC olvasóval valósítottam meg, amelyet a 3. ábrám ábrázol. Ezt a modult UART, SPI illetve I2C kommunikáció segítségével lehet a mikrokontrollerhez kapcsolni. A használni kívánt kommunikáció beállítását a két dipkapcsoló megfelelő pozíciójának állításával választható ki. A megfelelő állás meghatározásához a PCB n található leírás ad segítséget. 


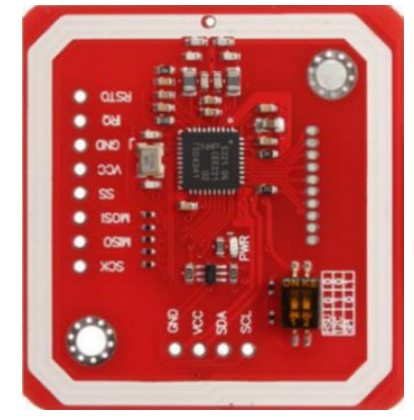

3. ábra PN532 NFC olvasó

\subsection{OLED kijelző}

Az OLED kijelzőt arra használom, hogy a felhasználó kapjon valamilyen visszajelzést arról, amit a gép végez. A kijelző segítségével győződhet meg mind a tanár, mind a diák, arról, hogy az az NFC címke, amit a diák az eszközhöz érintett, az valójában az ő nevét írja e ki. Ezzel mind a két fél megbizonyosodhat arról, hogy az eszköz a feladatát helyesen elvégezte. Mindezek mellett továbbiakban erre a kijelzőre egy menürendszert szeretnék tervezni, amellyel további információkat is ki tudna az eszköz a saját állapotáról jelezni. Az OLED kijelző 128 x 32 pixel felbontású, amelyen szinte bármilyen információ megjeleníthető. A mikrokontroller I2C kommunikáció segítségével tud kommunikálni a kijelzővel. Hozzám ez a kommunikáció áll a leg közelebb, hiszen négy vezetéken keresztül megvalósul a tápellátás és a kommunikáció is. Mindezek mellett az I2C adatkommunikációban több eszköz is részt vehet.

\subsection{Hordozhatóság}

Mivel az eszközöm egy hordozható eszköz lesz, ezért gondoskodnom kell az eszköz akkumulátoros üzemeltetéséről. Az eszköz által elvárt üzemidőnek nem kell túl magasnak lennie, hiszen viszonylag kevés ideig fog üzemelni. Mivel az eszköz müködéséhez szükséges minden komponensemet a mikrokontroller látta el tápfeszültséggel, ezért elegendő volt a mikrokontroller áramfelvételét vizsgálnom. A mikrokontroller áramfelvétele $5 \mathrm{~V}$ tápfeszültség mellett $170 \mathrm{~mA} \mathrm{t}$ vett fel. Ez úgy tevődött össze, hogy a mikrokontroller átlagos áramfelvétele $100 \mathrm{~mA}$, az NFC modul áramfelvétele átlagosan $30 \mathrm{~mA}$ NFC kártya olvasása és írása közben, az OLED kijelző $20 \mathrm{~mA}-\mathrm{t}$ vett fel, továbbá az RTC és az SD kártya modul $20 \mathrm{~mA}$-t fogyasztott [4]. Ha ki akarjuk számolni a teljesítményét az eszköznek, akkor az alábbi egyszerü képletet kell alkalmaznunk:

$$
P=U * I \text {, }
$$

amiből azt kapjuk, hogy az eszköz fogyasztása 0,75 W. Az eszközünk kb. 2 órát fog üzemelni egy nap folyamán. Azt szerettem volna, ha ezt az eszközt nem kellene minden nap tölteni, hanem körülbelül egy hetet tudna üzemelni egy feltöltéssel. Így értelemszerü, hogy egy 7,5 Wh-ás akkumulátort keressek, illetve hozzá egy töltésvezérlőt, hogy az akkumulátort minél könnyebb legyen tölteni és ne tudjuk túlmeríteni. Találtam egy 3,7 V $2500 \mathrm{mAh}$ akkumulátort, ami 9,25 Wh teljesítményt tud leadni. Ez az akkumulátor kicsit nagyobb, mint amekkora teljesítményre nekünk szükségünk lesz, de ha belevesszük a feszültség konvertálásakor keletkezö veszteségeket, akkor rádöbbentem, hogy erre a többlet teljesítményre is szükségünk lesz. 
Találtam egy olyan töltésvezérlőt, ami a Wemos D1 minivel és a kiválasztott akkumulátorral is kompatibilis. A töltésvezérlő -BMS- egy olyan elektronika, amely figyeli az akkumulátor feszültségét és sem túltölteni, sem túlmeríteni nem hagyja a cellát. Mindezek mellett a feszültség konvertálását is meg tudja oldani, így elegendő ezt a kiegészítő alkatrészt a D1 mini tetejére illeszteni és az akkumulátort ehhez az eszközhöz csatlakoztatni. Az akkumulátort a töltésvezérlőn található mikro USB csatlakozón keresztül lehet tölteni.

\section{Program fejlesztése}

Miután a föbb komponenseket megismertem, összekötöttem ezeket a mikrokontrollerrel. Ezek után elkezdtem a mikrokontrolleren futó program fejlesztését. Elöször az NFC modulból I2C kommunikáció segítségével próbáltam adatokat kinyerni, ami eleinte nem sikerült. Azt hittem, hogy a megírt programommal van a baj és ezért nem kapom meg az NFC kártya adatait. Érdemes odafigyelni az NFC modulon lévő dipkapcsolók állására, hiszen ez a hardveres hiba komoly fejtörést okozhat. Esetemben az NFC modulon nem az I2C kommunikáció volt kiválasztva. A dipkapcsolók megfelelő helyzetbe állítása után a mikrokontrolleren megjelentek az NFC kártya adatai. Az NFC kártya UID kiolvasása után azt az algoritmust kellett megírnom, ami hozzárendel ehhez a számsorozathoz egy nevet. Továbbiakban az UID hoz rendelt nevet fogja az OLED kijelző megjeleníteni. Ehhez meg kellett írnom azt a programrészt, ami az OLED kijelzőt kezeli. A megjelenített névnek ez után már csak a tárolását kellett megoldanom, úgy, hogy közben kiolvasom a RTC-ből a pillanatnyi időt.

A nyers program elkészítése után az eszköz megbízhatóságát vizsgáltam. Megpróbáltam olyan abnormális eseteket elöidézni, amelyek megzavarhatják a programom müködését. Közben a nyers programomat folyamatosan hibajavítottam. Miután az összes gyermekbetegségét kijavítottam a programomnak, feltöltöttem a mikrokontrollerre és a szerkezet bedobozolása után éles helyzetben is kipróbáltam.

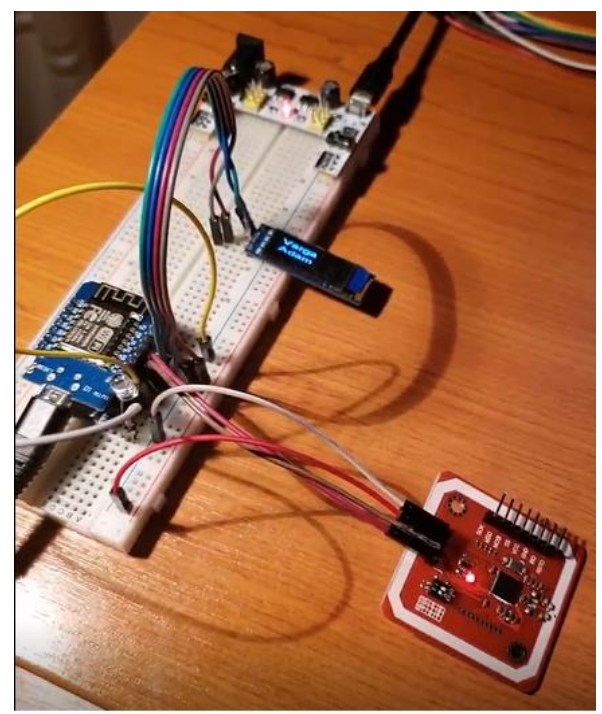

4. ábra. Katalógus vezető eszköz fejlesztés közben 


\section{5. Összefoglalás}

A katalógus vezető szerkezet köszönhetően a kompakt kialakításának és a nagyon alacsony fogyasztásának, nagyon hasznos szolgálatot tesz a katalógus vezetésében. Az eszköz a szorgalmi időszak első pár hetében csak próba üzemben üzemelt. Ezek után összehasonlítottam a papír alapú katalógust a digitális katalógussal, és azt vettem észre, hogy a papíron szereplö diákok neve 100\%-ban megegyezik a digitális formában vezetett katalóguséval. Az eszköz a próbaidőszak alatt megfelelően végezte a feladatát. Egyetlen esetben sem történt adatvesztés vagy hibás adatok rögzítése. Így a következő félévtől a katalógus vezetést ennek az eszköznek a segítségével fogom végezni.

Az eszköz egy feltöltéssel több mint egy hétig tudott üzemelni, így a kitüzött célomat kicsivel túlteljesítettem. Az eszköz töltése kifejezetten egyszerüen egy mikro USB kábel segítségével történik. A teljes feltöltéshez másfél órára van szükség 2 Ah tápegység esetén. A diákok nagy érdeklődéssel fogadták a szerkezetet és rengeteget kérdeztek az eszköz müködése felöl. Kifejezetten tetszett nekik, hogy nem papír alapon folyik a katalógus vezetés, hanem ez digitális formában történik.

\section{Köszönetnyilvánítás}

A cikkben ismertetett kutató munka az EFOP-3.6.1-16-2016-00011 jelü „Fiatalodó és Megújuló Egyetem - Innovatív Tudásváros - a Miskolci Egyetem intelligens szakosodást szolgáló intézményi fejlesztése" projekt részeként - a Széchenyi 2020 keretében - az Európai Unió támogatásával, az Európai Szociális Alap társfinanszírozásával valósul meg.

\section{Irodalomjegyzék}

[1] Szüts, Z., Jinil, Y.: Big Data, az információs társadalom új paradigmája. Információs társadalom: társadalomtudományi folyóirat, 2016, 16(1):8-28.

https://doi.org/10.22503/inftars.XVI.2016.1.1

[2] Király, R.: RFID alapú technológiák társadalmi és tudományos vonatkozásai. https://fr.slideserve.com

[3] Schwartz, M.: Internet of Things with ESP8266. Packt Publishing Ltd, 2016.

[4] Kodali, R.K., Makesh, K.S.: Low cost ambient monitoring using ESP8266. 2016 2nd International Conference on Contemporary Computing and Informatics (IC3I). IEEE, 2016. pp. 779-782. https://doi.org/10.1109/IC3I.2016.7918788 